\title{
Political Marketing Strategies Of Woman Candidates To Win The 2019 Provincial Legislative Election In Central Java
}

\author{
Yufanabila Risma ${ }^{1}$,Dian Eka Rahmawati ${ }^{2}$ \\ ${ }^{1}$ Study Program of Government Science/ Universitas Muhammadiyah Yogyakarta \\ ${ }^{2}$ Department of Government Science / Universitas Muhammadiyah Yogyakarta \\ ${ }^{1}$ Corresponding author: vufanabilar@gmail.com
}

\begin{abstract}
Political marketing strategy of legislative candidates is one of the important roles for the victory of a legislative candidate. This study aims to find out how Siti Ambar Fathonah S.Pd.I Political Marketing Strategy to Win the 2019 Legislative Election in Central Java. The research method used is qualitative research with a descriptive approach. Data collection techniques through interviews and documentation. The results of the study show that the marketing strategy carried out by Siti Ambar Fathonah has been going well with push marketing and pull marketing strategies that are used optimally in approaching the community. This marketing success brought him back to the legislative seat for the 2019-2024 period. However, it is not maximized in pass marketing, namely the use of social media as an arena for campaigning to the public. The 2019 Central Java provincial election is proof that political marketing plays an important role for Siti Ambar in gaining votes in the Golkar faction's electoral district II which brought her to the seat of the Central Java Provincial DPRD for the 2019-2024 period.
\end{abstract}

Keywords: Strategies, Political Marketing, Legislative, Women in Politic

\begin{abstract}
Abstrak: Strategi pemasaran politik calon anggota legislatif merupakan salah satu peran penting bagi kemenangan seorang calon anggota legislatif. Penelitian ini bertujuan untuk mengetahui bagaimana Strategi Pemasaran Politik Siti Ambar Fathonah S.Pd.I Memenangkan Pemilihan Legislatif 2019 di Jawa Tengah. Metode penelitian yang digunakan adalah penelitian kualitatif dengan pendekatan deskriptif. Teknik pengumpulan data melalui wawancara dan dokumentasi. Hasil penelitian menunjukkan bahwa strategi pemasaran yang dilakukan oleh Siti Ambar Fathonah sudah berjalan dengan baik dengan strategi push marketing dan pull marketing yang digunakan secara optimal dalam melakukan pendekatan kepada masyarakat. Keberhasilan pemasaran ini membawanya kembali ke kursi legislatif periode 2019-2024. Namun, belum maksimal dalam pemasaran lewat media sosial yaitu pemanfaatan media sosial sebagai ajang untuk berkampanye kepada masyarakat. Pilkada Jateng 2019 menjadi bukti bahwa pemasaran politik berperan penting bagi Siti Ambar dalam mendulang suara di dapil II Fraksi Golkar yang membawanya menduduki kursi DPRD Provinsi Jateng periode 2019-2024.
\end{abstract}

Kata kunci: Strategi, Pemasaran Politik, Legislatif, Perempuan dalam Politik

Article History:

Received : 2020-11-07

Revised : 2020-12-01

Accepted : 2020-12-20

\section{INTRODUCTION}

Indonesia is a country that adheres to a democratic system in which sovereignty is held by the people, yet in its implementation, it is handed over to the representatives of the people who sit in parliament so there are many political parties have been formed. Political parties become liaisons for citizens to participate and actively participate in elections. Political parties are used as political institutions that serve to collect and articulate various interests of the people. The implementation of democracy that is expected by Indonesia for political parties has not shown significant changes to the social, economic and political maturity of the people. Indonesian political parties have not been able to provide a balanced share for participating societies and play an active role in politics, especially women based on (Fauzi, 2010). According to (Bari, 2009), the presence of women in the political sphere is still very low although the Indonesian constitution does not provide restrictions on women's political 
participation and representation. The involvement of women in public life has indeed increased, but the participation of representation in national and provincial legislatures and other government agencies is still low. To justify the gender imbalance in the national, subnational and local legislatures, the Law No. 2 of 2008 was published that contains a policy that requires political parties to include at least $30 \%$ female representation in the establishment and in management at the central level. This figure is based on United Nations research which states that a minimum of 30 percent allows for a change and has an impact on the quality of decisions taken in public institutions. Then, in the Law No. 10 of 2008, it is affirmed that new political parties can follow political institutions after meeting the requirements of including at least $30 \%$ female representation in the management of central political parties. Another rule is to implement a zipper system which regulates that every 3 candidates, there is at least one female person. This provision is contained in the Article 55 paragraph (2) of Law No. 10 of 2008. Both policies aim to avoid the dominance of one gender in political institutions that formulate public policy.

The representation of women in elections in this legislature is an important concern for political parties because the presence of women actively involved in politics is able to authorize women to make policies directed to women in achieving women's rights, especially gender equality. In addition, the low representation of women is still widely adhered to patriarchy in most societies that tend to place women's positions under male rule. According to Abdurrachman et al. (2019) assert that based on global developments on increasing the role of women that have been carried out by various countries, the wisdom and strategy of increasing the role of women in Indonesia is basically seeing women in its various positions and functions, by reaching to the social, economic, political, cultural, religious, and family dimensions. Because the improvement efforts are related to various fields, the handling is implemented intersectoral integrated, and multidisciplinary.

In Central Java Province, the total number DPRD is 100 people, consisting of 76 male members (76\%) and 24 female members (24\%) in the 2014 Election. For the region itself in the 2014 elections, of the 35 districts/ cities in Central Java, women members from District/City Parliament were more elected than major political parties, such as Partai Demokrasi Indonesia Perjuangan (PDIP), Partai Demokrat, Partai Golongan Karya (Golkar) and Partai Kebangkitan Bangsa (PKB).

Meanwhile, in the 2019 the election of DPRD in Central Java Province, the legislative candidates increased to 120 people, consisting of 23 women and 97 men (dprd.jatengprov.go.id). In the 2019 General Election, Siti Ambar Fathonah ran as the only female incumbent from Golkar Party. In the previous election, Siti Ambar Fatona received 30,273 votes while in the 2019 General Election, she managed to apply 21,215 votes (jateng.kpu.go.id). Despite advancing as the only female incumbent, Siti was able to win the 2019 General Election.

This is certainly supported by Siti Ambar Fatona's status as an incumbent candidate so that it has the initial capital in the form of social capital and should not need too much financial capital to win the 2019 Election in Central Java. In addition, Siti Ambar Fatonah was once the only female Ungaran Regent elected in 2006-2010, so Siti has enough capital to increase her electability to advance in the 2019 Election. Not all incumbent legislative candidate can be elected again and only Siti Ambar is the only woman from Golkar Party who was re-elected in the 2019 General Election. Not only that, in the middle of the election for the Legislative candidate for the election of Central Java Province, Siti Ambar Fatonah fulfilled the invitation of a community leader in the association, suspected of committing money politics because in the middle of the event, she introduced herself as a legislative candidate to local residents accompanied by asking for citizen donations. That is why it was 
suspected that money politics was then reported to the realm of law, but Siti Ambar Fatonah appealed against the accusation and finally she was freed from the sentence. That was interesting to look at because through observing the voter data in 2014 and 2019 female legislative candidates are declining, but they can still keep and win two terms from Golkar. Therefore, this research is going to find the Political Marketing Strategies of Woman Legislative Candidate to Win the Provincial Election of Legislative Candidates in 2019 under a Case Study of Siti Ambar Fathonah as the Woman Representative in Dapil II Central Java Province.

\section{RESEARCH METHOD}

This research was conducted using a qualitative descriptive method through a case study approach. According to Sugiyono (2013), qualitative research method is a research method based on the philosophy of positivism and used to examine the natural conditions of objects where the researcher is a crucial instrument. Data analysis was qualitative research results emphasized more meaning than generalization (Sugiyono, 2008). Case study research is a qualitative approach who the research explores real life; a system that is limited by cases or various cases, through the collection of detailed and penetrating data, involving various sources of information, and reports on case descriptions and case themes. This research was conducted in Central Java Province by focusing on the member of DPRD in Dapil II, namely Siti Ambar Fatonah. Additionally, the focal point of this research is the Electoral Commission.

\section{RESULTS AND DISCUSSION}

Siti Ambar Fathonah is a woman born in Semarang Regency, precisely on November 21, 1958. Siti Ambar Fathonah lives in Pringsari Village, RT 01/RW 01, Pringapus District, Semarang Regency, and she is Muslim and married. Before Siti Ambar Fathonah set foot in the world of politics, previously she was an entrepreneur and then turned to spread to the world of politics. From the beginning of her career, she had participated in many organizations and joined the Golkar Party, and her political career began to develop. Before Siti Ambar Fathonah became a member of the Golkar party council for the Central Java Provincial DPRD, she was an active politician only in the Golkar party and over time she later served as a member of the Central Java Provincial DPRD for the 2014-2019 period and the former of Deputy Regent of Semarang for the 2005-2006 period as well as the Regent of Semarang for the period 2006-2010. Then, she re-nominated herself as a candidate for a member of the Central Java Provincial DPRD in the 2019-2024 period from electoral district II. In the 2014 and 2019 legislative elections, Siti Ambar Fathonah earned a point of victory. Apart from serving as a Regent and Deputy Regent of Semarang Regency, she as an entrepreneur is also active in organizations.

The unpretentious figure of Siti Ambar Fathonah and a lot of socialization make it easier for social and cultural approaches to the community to gain votes and deliver the figure of Siti Ambar Fathonah to the 2019 election seat in Central Java Province. She is also the only woman who has the most votes in the Faction. Golkar members from Dapil II of the Golkar Faction. The following is the number of permanent candidates for legislative members in Dapil II DPRD of Central Java Province in the form of a table.1:

Table 1. Electoral District II 2019 Legislative Election (Semarang, Kendal, Salatiga City) 


\begin{tabular}{lcc}
\hline \multicolumn{1}{c}{ Parties } & Amount & Presentage \\
\hline Kebangkitan Bangsa Party & 7 people & $43 \%$ \\
\hline Gerindra Party & 7 people & $43 \%$ \\
\hline PDI Perjuangan & 7 people & $43 \%$ \\
\hline Golkar Party & 7 people & $43 \%$ \\
\hline Nasdem Party & 6 people & $50 \%$ \\
\hline Garuda Party & 2 people & $50 \%$ \\
\hline Berkarya Party & 5 people & $40 \%$ \\
\hline Sejahtera Party & 6 people & $50 \%$ \\
\hline Perindo Party & 6 people & $33 \%$ \\
\hline Persatuan Pembangunan Party & 7 people & $43 \%$ \\
\hline Solidaritas Indonesia Party & 3 people & $67 \%$ \\
\hline Amanat Nasional Party & 7 people & $43 \%$ \\
\hline Hanura Party & 3 people & $33 \%$ \\
\hline Demokrat Party & 7 people & $43 \%$ \\
\hline Bulan Bintang Party & 3 people & $33 \%$ \\
\hline Keadilan Dan Persatuan Indonesia Party $\quad$ Source: Central Java Province & DCT, 2019 & $0 \%$ \\
\hline
\end{tabular}

The number of provincial DPRD candidates who took part in the 2019 legislative elections in Central Java Province in Dapil II was 83. While the composition of candidates in Dapil II based on gender there were 40 female candidates and 43 male candidates. In accordance with the election law, a 30\% quota of legislative candidates who took part in the election, especially in Dapil II. The list of candidate names can be seen in the following table.2:

Table 2. List of Candidates for Members of the 2019 General Election Golkar Party

\begin{tabular}{lr}
\hline \multicolumn{1}{c}{ Name } & Number of Vote \\
\hline H. Yusuf Hidayat & 18.605 \\
\hline H. Iryanto & 6.590 \\
\hline Siti Ambar Fathonah, S.Pd & 21.215 \\
\hline Sasmito, S.H., M.H & 9.814 \\
\hline Jamsari, S.I.Kom & 3.515 \\
\hline Setiarini Tjatur Rahaju, S.H & 821 \\
\hline Dian Rossi Arnita & 2.459 \\
\hline
\end{tabular}

Siti Ambar Fathonah as a figure of women being able to occupy legislative seats and why women have rights in politics. Siti Ambar Fathonah, who as a person who can be modest and puts the public interest ahead of her own interests, is able to give a positive image in the eyes of the community and also her work colleagues. Siti Ambar Fathonah brings her leadership spirit, friendliness and familiarity with the surrounding community and her colleagues by going directly to the community and absorbing the aspirations of the community related to community empowerment and women. This makes Siti Ambar Fathonah focus her political marketing strategy on the underprivileged people who need a lot of changes. Thus, the Vision and Mission carried by Siti Ambar Fathonah, including:

Vision

"Participate in creating a just and prosperous Indonesian society through strong superior human resources in the unitary state of the republic of indonesia by continuing to work and 
transform in accordance with the development of the times to achieve the Nation's Ideals based on Pancasila and the 1945 Constitution".

\section{Missions}

a. Encouraging Plurism in Unity by Accommodating the Indonesian Nation in accordance with the motto Bhineka Tunggal Ika.

b. Maintaining the Commitment to the Progress of Democracy while Maintaining the Basic Values of the 1945 Constitution.

c. Struggling consistently to realize the welfare of justice and people's intelligence as a whole, reduce poverty and unemployment, increase income, improve the quality and equity of education and improve public health.

d. Maintaining commitment in upholding the formation of law and human rights as well as realizing a clean government in a constitutional democratic way of life.

e. Developing appreciation of moral and ethical values sourced from religious teachings to increase faith and piety as a source of motivation and inspiration in development.

f. Realizing the management of natural resources as well as efficient, efficient and sustainable use and care for the environment.

g. Building solidarity and social loyalty to create resilience in a pluralistic society.

In accordance with the vision and missions carried out by her, then, a work program is formed. With the alignment of the vision and missions brought by Siti Ambar Fathonah, it brought her to the trust of the people in choosing her. Maximizing victory in the general election depends on the effectiveness and efficiency of the application of political marketing so that it reaches its goals. In this context, the legislative general election Siti Ambar Fathonah, S.Pd.I applied the political marketing into a form of team groups that functioned as winning teams in the electoral district II, Central Java Province, and the use of such posts as pre-election support posts for legislative candidates. This is what bridges and facilitates the meeting of Siti Ambar Fathonah, S.Pd.I with the community to meet face-to-face and interact with the community

Table .3 Votes for the Electoral District II

\begin{tabular}{ccc}
\hline Elected legislature & Party & Number of Voters \\
\hline H. Benny Karnadi, S.Ag. & PKB & 49.848 \\
\hline Mifta Reza NP, S.P., M.M. & Gerindra & 37.510 \\
\hline H. Bambang Kusriyanto, B.Sc. & PDIP & 125.820 \\
\hline Dyah Kartika Permanasari, S.E., M.M. & PDIP & 75.713 \\
\hline Siti Ambar Fatonah, S.Pd. & Golkar & 21.215 \\
\hline Hj. Ida Nurul Farida, M.Pd. & PKS & 37.849 \\
\hline Dr.Hj. Sholeha Kurniawati & PPP & 33.864 \\
\hline
\end{tabular}

Source: Indonesian Political Geospatial Data, 2019 
The total seats obtained from the electoral district II Central Java were 7 seats up for grabs. In the 2019 legislative election, of the 7 seats, Siti Ambar Fathonah won the seat with a total of 21,215 votes. Siti Ambar Fathonah is the only female cadre from Golkar to gain a seat in the second electoral district of the Central Java Legislative Election. Siti Ambar Fathonah's winning strategy in the legislative election is strongly influenced by how candidates can influence voters for the purpose of shaping voter behavior. Basically, candidates are producers who are able to market themselves as a political marketing process.

Siti Ambar Fathonah's victory in the 2019 Central Java Provincial legislative election was influenced by a well-packaged political marketing strategy to attract people's attention. The victory was assisted by several successful teams or the formed core team to help Siti Ambar Fathonah get the most votes. From the victory obtained by Siti Ambar Fathonah, the researcher analyzed using 3 models of political marketing elements proposed by Adman Nursal, involving: Pass Marketing, Push Marketing, and Pull Marketing.

\section{Push Marketing}

Push marketing is a political marketing effort by conducting direct or face-to-face meetings with voters to make the prospective voters willing to support the political contestants concerned. This strategy can be considered as a blusukan with the aim of bringing the political contestants closer to the voters. In push marketing strategy, Siti Ambar Fathonah and her core team are trying to get closer to the community, especially in the Regional Elections II Semarang Regency, Kendal Regency and Salatiga City, the people who come to the voting booth to vote for themselves. Another Push Marketing strategy that she carried out was by conducting campaigns to the community through religious activities because the figure of Siti Ambar Fathonah who is also active in women's organization activities. The Push Marketing strategy will make people feel recognized and will unconsciously carry out a promotion or campaign to the people around them.

"She met door to door with the community, discussed with the community, had a dialogue with them, asked about their hopes and aspirations for the government, convinced the public with the vision and mission that I brought as a legislative candidate to accommodate and realize the aspirations of the people."

Through the interview with one of her team members, namely Mr. Supraptono, the researcher analyzed the push marketing strategy used by Siti Ambar Fathonah and her core team that conducted door to door with the community and invited discussions to find out what the community's expectations and problems were of concern. This approach was used by Siti Ambar Fathonah and her core team by providing rational input to the community to be willing to support Siti Ambar Fathonah. Siti Ambar Fathonah, who is often and active in community activities, especially in women's Muslim organizations from the village level to the provincial level, played a lot of roles and socializes with women, as a candidate for representatives of the people who really cares about the community. In addition to the approach by playing an active role in women's organizations, the process carried out by Siti Ambar Fathonah made the public as consumers of push marketing strategies, inseparable from the goal of getting people's hearts back, so they could vote for Siti Ambar Fathonah in the 2019 legislative elections. She built personal relationship with the community, especially women, as expressed by Rismautami as a community: 
"Before Mrs. Ambar wanted to run as a legislative candidate, she always came to Muslimat events around her house and often became the head of a Muslim group. Known as a person who enjoys and cares about the environment."

In the interview, Siti Ambar Fathonah participated in activities held by the community and participated in mingling and personal discussions with the aim of knowing the wishes of the community or policies that had not been realized. As an Advisor to the NU Muslimat of Semarang Regency, of course, she also provides a lot of motivations to always live side by side and always obeys to the Creator, through strong piety so that she believes that people can choose leaders who are able to bring their people to goodness. In addition, one of the people, who had participated in a women's organization along with Siti Ambar Fathonah, revealed:

"Most of her voters are female voters because she follows many Muslim women's organizations, so they know Mrs. Ambar in Semarang Regency. This emotional closeness factor is the main factor and there is also a campaign intent for her. The community directly goes through several activities that are held".

The emotional closeness that Mrs. Ambar always brings in approaching the community was the key so that she could confidently know what the community wanted and the complaints that occurred. Many candidates for representatives of the people also paid less attention to women even though the role of women was very important here. One of the communities said:

"The programs that are delivered are automatically related to empowerment of women in the family sector".

Mrs. Ambar also provided a lot of education so that women could be more introspective and also be brave to speak in public. Not only that, Mrs. Ambar gave a lot of insight and also trained mothers' self-confidence both in household matters and also in independence. Women are not only as companions for their husbands, but also the role of women can help their own life especially how to educate children to prepare for their future in the field of education. That was where the forerunner to the number of voters from Mrs. Ambar from among women because her fellow women really uphold the value of equality. There were no differentiated rights as women and men. She also has a good image not only among women, but also among all people as long as she is the people's representative.

Through the interview above, Mr. Supraptono also made it clear that the push marketing political marketing strategy activities carried out by Siti Ambar Fathonah showed that even though she came from an incumbent legislative candidate, Siti Ambar Fathonah would try to get closer to the community, both from the middle to the lower community as the target of her voice. In the Push Marketing process, Mrs. Ambar also did not have a volunteer team, meaning that as an organization she had never formed volunteers, so she only built it from the accesses of our colleagues, who were self-aware of what Mrs. Ambar had so that they are interested in casting their votes in the legislative elections.

\section{Pull Marketing}

Pull Marketing strategy uses the media as the formation of the popularity of political contestants. Political contestants must build a good image so that voters can make their choices as expected. The media are required to maintain the contestants' campaigns and work programs by conveying an impressive message into the minds of the public. The strategy must contain all the handling of problems faced by the community. The pull marketing strategy is an interesting thing in the formation of self-image which aims to convince the public that the political message is conveyed consistently and repeatedly, so it is easy for the public to remember. The use of the pull marketing strategy is used by Siti Ambar Fathonah and her 
team with the presence of electronic media or the use of social media and conventional media (print media). The following is an interview revealed by Siti Ambar Fathonah's core team, one of her tem says:

"In the 2019 election, there are many intensive legislative candidates who also go through social media, but we still use conventional media in introducing Mrs. Ambar to the public".

Therefore, the most widely used was conventional media through posters affixed in several places. So, if the initial use of conventional media was in the form of interviews and advertisements in print media, then there are some local online media, such as Radar Jateng, either in the form of interviews or coverage of activities. Mrs. Ambar, who is known as an incumbent legislative candidate, of course already had a name with the previous position and was often visited by journalists to be better known by the citizens. Mr. Supraptono as the head of the core team explained that:

"There is no internet or other media. We only do face-to-face meetings with the community and install pictures and socialize how to vote correctly, especially on the expected target."

The pull marketing strategy of Siti Ambar Fathonah's team is more focused on conventional media than social media. When carrying out a pull marketing strategy using conventional media, such as interviewed by journalists, Siti Ambar Fathonah is required to make many statements or political messages that are conveyed to form a positive image in the community. In addition to the use of conventional media and social media, Siti Ambar Fathonah used banners and pamphlets and intensively socializes to the public by providing guidance regarding the procedures for choosing the right way to legislative candidates Siti Ambar Fathonah to the public.

As stated in the interview above, the use of media for political marketing strategies was less effective. The use of public physical space as an arena for self-promotion of legislative candidates to attract people's attention actually made people feel that the delivery of messages through conventional media was less than optimal. This is reinforced by the residents' statements as follows:

"As an ordinary citizen, you often see pamphlets, billboards, and banners on the street. Personally, I think there is a positive side to introduce Mrs. Ambar in the community, even though she is already quite well-known because she is an incumbent legislative candidate, by rebranding her name with the position she used to have occupied".

Dealing with the difficulties experienced by Siti Ambar Fathonah in conveying messages in the media was changed by holding direct meetings with the community by conveying messages that were pleasing to the people's hearts through direct meetings and also taking advantage of her side as the Regent and Deputy Regent of Semarang Regency. She realized the aspirations of the people for the common welfare of the people of Central Java Province.

\section{Pass Marketing}

Pass marketing is a political marketing strategy that involves influential individuals or groups (influencers) to convince voters. Influencers used by contestants can be community leaders, social organizations and masses who are very influential for voters. These influencers influenced opinions and convinced voters to vote as well as supported Siti Ambar Fathonah in the 2019 legislative elections in Central Java Province. The pass marketing strategy was carried out by Siti Ambar Fathonah to establish relationships with influencers to be able to 28 
continue the political messages conveyed by Siti Ambar Fathonah to the public. This strategy will be successful if it is carried out with the most appropriate person or group in gathering the masses who can be influenced by the influencer's opinion.

The use of pass marketing for the contestants was very influential in conveying political messages to the community through people or groups who had influence, especially in Central Java Province. Mrs. Siti Ambar Fathonah held communication with local community leaders, such as meeting with RT RW, religious leaders such as local clerics by building discussions to find unresolved problems. As stated by head of neighbourhood:

"I know Mrs. Ambar as a respected figure, and her family whose ethics and manners in society provide added value in the eyes of the community".

The procedure that Siti Ambar Fathonah did to encourage the community leaders was to convince and maintain their belief which the method or political product offered by Siti Ambar Fathonah was correct although there were few obstacles for her to convince several people and also the community leaders because even though they came from from the incumbent candidate, she had stumbled upon a money politics case in the year that she served as a candidate for Regent.

Siti Ambar Fathonah and her core team tried to continue to convince these important figures by using a persuasive approach so that the community leaders and individuals felt confident in the political products presented by Siti Ambar Fathonah, and could deliver the product politics to society of that approach. With the strength of big public figures, coupled with her recognition as a former Regent and Deputy Regent, the public would have known about her performance and work ethic while she was in office. Undaunted by the unproven political case, the community was confident again so that Siti Ambar Fathonah could bridge the community in accommodating their aspirations. In an interview conducted by the author with Mr. Supraptono as a success team, he also claims that:

"It is the community leaders who then act like long arms and can then convey messages, automatically about the whereabouts of Mrs. Ambar who is related to her work ethic when carrying out tasks at the regent of Semarang district".

The figure of Siti Ambar Fathonah who is known to be active in dealing with many organizations certainly had an impact on winning Siti Ambar Fathonah's vote. They are highranking figures who are also confident in the performance that she instilled during her tenure. Quoted by Sinar Jateng, the Secretary of Commission B, Muhamad Ngainiirrichadl, revealed that Siti Ambar Fathonah is known as a good person, diligent in worship, willing to share and protector.

"She is a good person, very caring, an expert in worship, reciting/tadarus al-Qur'an and even often do one juz per day or one day one juz (ODOJ), " he said.

Meanwhile, according to the Chairman of the Golkar Party's DPP for the Winning of Central Java and DIY Elections, Dr. HM Iqbal Wibisono says that Siti Ambar Fathonah is known as a potential Golkar Party figure, well behaved, easy to get along with, and has a wide network. The network that she brought was not only from the influencer figure in his party, but also from someone who she always maintains and trusts. With a sense of togetherness, plurality, unity and oneness, that is what finally motivated them to work on Siti Ambar Fathonah's work program. There was no longer a difference in party background with that being the value of pluralism, and the relationship is not only from a particular party but 
remains in the initial commitment. When Siti Ambar Fathonah returned to run for the next election, the community and her work colleagues saw the vision of togetherness that was built together at that time. The existing potentials were used as a shared vision and mission for mutual cooperation, which essentially prioritizes the value of togetherness. The realization of economic development in stages and social justice for all people in accordance with the principles of Pancasila could not be forgot because all of them must be based on religious values, and practiced well. Social life as an Indonesian nation remains the essence of Bhinneka Tunggal Ika, with different backgrounds remaining one.

\section{Obstacle Factor}

As the incumbent candidate, Siti Ambar Fathonah, in the previous period with the current period and the vote decreased, although she still received an allocation of DPRD seats, it was unfortunate that the political marketing strategy in such a way experienced a decrease in votes. According to Mr. Supraptono narrative as one of the teams that helped Siti Ambar Fathonah he states:

"The factor in the decline in votes from the previous period's acquisition is indeed problematic from within the party that Siti Ambar Fathonah carries itself; one of which is the priority of affiliated candidates".

In this election, Siti Ambar Fathonah was not actually a priority in the Golkar Party that was promoted by herself. It turned out that there were several candidates who wanted to win the seat allocation. At that time, the Golkar Party encouraged people from the Golkar Party affiliation (a party that formed a coalition or used a new party for election purposes) to win the election. At that time, the Golkar Party prioritized the people from Golkar Party affiliations compared to people who were pure from the Golkar Party for the sake of obtaining maximum votes for the Golkar Party. Even, the team from Siti Ambar Fathonah divided the focus to provide support to these sympathizers. Among them, there were three sympathizers whose votes were almost even or the same in the calculation. Threfore, both of them got votes and also different seat allocations from before, which during the campaign only focused on one vote so that they got more votes compared to this period.

Furthermore, the decrease in votes from the previous period was not due to public who distrust of Siti Ambar Fatthonah because she was suspected of being involved in money politics or moving electoral districts, but one of them was because the Golkar Party prioritized people from the party coalition so that the focus of the vote was divided with other candidates party priority. However, this is not a barrier for Siti Ambar Fathonah, who has held positions in the government structure several times. The political branding that he embeds in the community's perspective is able to make people believe even though there are obstacles and even allegations of Siti Ambar Fathonah who are actually not proven guilty.

\section{Successfully Factor}

In the political marketing theory promoted by Siti Ambar Fathonah, it turned out to have a great influence on the voters. Her figure was widely judged by the public as a charismatic leader candidate, so these messages could be conveyed subtly and also openly to direct voters to choose or not to choose certain contestants. Some carried out activities with a neat organization and others informally through a religious activity. The vision and mission of Siti Ambar Fathonah since the first legislative election until the second election also maintained her figure as a reliable female leader. 
The re-election of the figure of Siti Ambar Fathonah to become a member of the legislature was for one reason, because she can embrace all parties in the spirit of togetherness and plurality that were the main thing. Even though she comes from Golkar, not only Golkar people who vote, but also other parties also chose him, so not from the background of her party. From the background of her figure, she is a gentle and humble figure in the eyes of the community and also his work colleagues. Not only from the rich and poor, everything is accepted very openly by her.

As one of the incumbent candidates from the Golkar Party, Siti Ambar Fathonah was not an independent candidate because she still had ties to political parties, if she was not tied to a political party. According to existing regulations, she could not participate in elections. Siti Ambar Fathonah is one of the female figures who becomes one of the independent female representatives who is able to sit in the legislative seat as an individualist who is bound through her party, not as an independent.

For reaching to her point of success again so that she was re-elected as a member of the legislature in the 2019-2023 period, of course the challenges she faced were also different. The figure of Siti Ambar Fathonah did not have a special team or a successful team from her party group. Only a few people were trusted and always defended, because one of the reasons that she doesn't have a successful team is that party people had other candidate priorities.

However, in our social life, we must be the same as the Indonesian nation, still in the essence of Bhinneka Tunggal Ika. No wonder when the nominations for the two values were re-applied and remained embedded in the public's trust with the unpretentious figure that Mrs. Ambar brought, so people continued to believe that she deserved to serve again as a legislative member in Central Java Province for the 2019-2023 period as a woman elected to sit in politics.

\section{CONCLUSION AND SUGGESTION}

The presence of women in political parties certainly has a quite different effect in the world of politics, but in carrying out its role in politics women experience several. In general, there are 3 obstacles experienced by women, namely social culture barriers, psychological barriers, and economic barriers. Barriers to social culture that are still often faced are the public's view that it is strange when a woman is active in the activities of political parties. However, Siti Ambar Fathonah was able to break through this, she was able to brand herself in order to get a good image from the views of the community and also her work colleagues. She is able to read the situations and opportunities that exist in society, for example, with the 3 political strategies she does. The 2019 Central Java Provincial Election is proof that political marketing plays an important role for Siti Ambar Fathonah in gaining votes in the Dapil II region of the Golkar Faction which brought her to the seat of the Central Java Provincial DPRD for the 2019-2024 period. Siti Ambar Fathonah uses a political marketing strategy as a way for two-way communication by involving ideas and ideas to constituents.

Political marketing strategies, namely Pass Marketing, Push Marketing, and Pull Marketing, have been running in theory. However, it also has a strategy that is not maximized in Siti Ambar Fathonah's victory. Siti Ambar Fathonah's victory factor in doing political marketing. First, Siti Ambar Fathonah's success in winning the 2014 and 2019 legislative elections in Semarang Regency, Kendal Regency and Salatiga Regency as electoral district II by utilizing a push marketing political marketing strategy with the community in a persuasive approach. Second, the political marketing strategy of Pass Marketing Siti Ambar Fathonah and the team by showing more value in the eyes of the community plus him as an incumbent legislative candidate who is better known among the public and also community leaders for his work ethic when carrying out obligations while serving as a Member of the Central Java 
Provincial DPRD and Vice Regent of Semarang Regency and Regent of Semarang Regency, that's where the community saw what he had given to the people of Semarang Regency, namely in the form of concern for the situation and shortcomings of the lower class community and emphasizing religious tolerance.

While the inhibiting factors for Siti Ambar Fathonah are, first, the lack of utilizing social media as a place to campaign well through influencers in electronic media who can support as a means of supporting Siti Ambar Fathonah's political marketing tools. Second, there is a stronger push from the Golkar Party to the Affiliated Party so that the votes are also distributed in the form of a campaign so that other candidates get almost the same votes. This research is only limited to supporting and inhibiting factors as well as the process of political marketing activities carried out by legislative candidates at the district level. Hopefully this research can make a good contribution to further research in political science, especially the study of political marketing by being enriched with more recent theories. The researcher suggests that in the upcoming elections for political parties to prepare the best political candidates which includes the formation of a good image and track record, the aim is that the public will not only be consumed by promises made only by candidates. It should also be noted that political candidates should involve novice voters as targets for political marketing strategies, because the influence of novice voters has the potential to increase votes. Researchers suggest for success teams from parties and non-parties to involve youth because youth have great potential in human resources, especially in the use of social media. The goal is to make it easier to carry out political marketing strategies by reaching all circles.

\section{REFERENCES}

Abdurrachman, H., Riyanti, R., \& Nugraha, R. A. (2019). Kuota Perempuan Di Dprd Jawa Tengah Pada Pemilu 2014 Dan Pemilu 2019. Perspektif Hukum,

pribadi. (2014). EFEKTIVITAS PENCAPAIAN AFFIRMATIVE ACTION KUOTA 30\% PEREMPUAN OLEH PARTAI POLITIK DI DIY PADA PEMILU 2014.

Artina, D. (2016). Keterwakilan Politik Perempuan dalam Pemilu Legislatif Provinsi Riau Periode 2014-2019. Jurnal Hukum IUS QUIA IUSTUM,

Badrul, M., Studi, P., \& Informasi, S. (2015). Prediksi Hasil Pemilu Legislatif Dengan Menggunakan Algoritma K-Nearest Neighbor. Jurnal Pilar Nusa Mandiri, XI(2), 152160.

Bari, F. (2009). PEREMPUAN DI RANAH POLITIK. Lembaga Studi \& Advokasi Masyarakat $\backslash, 2,3500$.

Bela, H. S., \& Utama, A. S. (2020). Motivasi Partisipasi Politik Perempuan Pada Pemilu Legislatif 2019 di Kabupaten Ogan Komering Ulu. 5(2), 41-49.

Dalupe, B. (2020). Kandidat Perempuan dan Tantangan Politik Patronase pada Pemilu Legislatif 2019 di Provinsi Nusa Tenggara Timur. 3(1), 15-34.

Dwika Paradita, W. (2019). Partai Politik Dan Kontestasi Perempuan Dalam Pemilu 2019 Di Kabupaten Batang. Ilmu Sosial, Unnes, 281-294.

Izdiha, A. (2017). Wajah Politik Perempuan: Studi Etnografi Representasi Suara Perempuan dalam Pemilu Legislatif 2014 di Propinsi Daerah Istimewa Yogyakarta (DIY). Jurnal Pemikiran Sosiologi, 
Jovani, A. (2018). Potret Keterwakilan Politik Perempuan Anggota Legislatif di DPRD NTT pada Pemilu 2014. Jurnal Inada: Kajian Perempuan Indonesia Di Daerah Tertinggal, Terdepan, Dan Terluar,

Ningsih, R. T. A. (2016). Keterwakilan Perempuan dalam Pencalonan sebagai Anggota Legislatif oleh Partai Politik di Kabupaten Berau. Jurnal Ilmu Pemerintahan, 4(4),

Ramadhany, D., \& Rahmawati, D. E. (2020). Modal Caleg Perempuan dan Politik Patriarkhi dalam Pemilihan Umum di Indonesia: Keterwakilan Perempuan pada Pemilu 2019 di Kabupaten Sleman. JISPO Jurnal Ilmu Sosial Dan Ilmu Politik,

Komisi Pemilihan Umum Jawa Tengah (2019). Accessed on February, 22021 in https://jateng.kpu.go.id

Pemilihan DPRD Jawa Tengan (2019). Accessed on January, 82021 in https://dprd.jatengprov.go.id/

Print Buletin Bawaslu Kabupaten Semarang. Accessed on March, 22021 in https://semarangkab.bawaslu.go.id/wp-content/uploads/2019/09/PRINT-BULETINBAWASLU-KAB-SEMARANG. 